\title{
The diversity of the top management team and the survival and success of international companies: The case of Spanish companies with foreign direct investment in China
}

\author{
Angels Niñerola \\ Universitat Rovira i Virgili \\ angels.ninerola@urv.cat \\ Ana Beatriz Hernández-Lara \\ Universitat Rovira i Virgili \\ anabeatriz.hernandez@urv.cat \\ Maria Victòria Sánchez-Rebull \\ Universitat Rovira i Virgili \\ mariavictoria.sanchez@urv.cat
}

\begin{abstract}
There is an important stream of research in internationalisation studies about the influence of governing bodies on organisational expansion strategies. Using Upper Echelon Theory, this paper aims to analyse how the diversity of the top management team affects the success and survival of the company abroad. Data were collected from Spanish companies with foreign direct investment in China during the period 2012-2013. China was chosen as the host country because it is the world's largest recipient of FDI and because of the considerable cultural and geographical differences between China and Spain, which make the investments especially risky and uncertain. Therefore, it deserves additional research. The results indicate that a top management team with members of very different ages has a negative impact on the success of the company abroad because the generational differences introduce different opinions into decision-making process. However, gender diversity increases the survival of the company. Survival is also greater if the company is smaller because it is more flexible and has a greater ability to adapt to market contingencies.
\end{abstract}

Keywords: Upper-Echelon Theory, business strategy, internationalisation, top management team, Spanish companies, China. 


\section{Introduction}

In the current economic environment, many companies seek to expand their domestic market in search of new customers and profits. In this respect, internationalisation is recognised as a valuable strategy for growing organisations (Graves and Thomas 2008). But it is also a strategic decision that involves high risks and uncertainty for companies (Contractor et alii 2007; Musteen et alii 2009). This dichotomy of internationalisation, the effects of which are contradictory, is what makes this corporate strategy an important area of study in business research.

There is a stream of internationalisation research on the influence of governing bodies on the expansion strategy of companies because of their responsibility as the agents of decision-making (Wiersema and Bantel 1992; Westphal and Fredrickson 2001; Hsu et alii 2013).

In this respect, the Upper-Echelon Theory, developed by Hambrick and Mason (1984), studies the implications of the demographic characteristics of managers on organisational results (Kilduff et alii 2000; Pegels et alii 2000; Auden et alii 2006). These demographics can influence, and are used as a proxy for, the values and beliefs of members of the governing bodies and, therefore, as determinants of their decisions (Finkelstein and Hambrick 1996). Previous research has highlighted objective and easily measurable demographic characteristics such as age, tenure, function or training (Hambrick and Mason 1984; Tihanyi et alii 2000). However, considering that those responsible for decision-making do not normally act alone or independently (indeed they usually constitute working groups) previous research has also searched for measures of these demographic variables that cover the whole group, focusing mainly on the impact that the demographic diversity of these variables has (Kilduff et alii 2000; Díaz-Fernández et alii 2014). Many studies have used this theory to explain the impact on various measures of organisational performance and strategic outcomes, such as internationalisation strategies, but most of these have used North American samples and not drawn any conclusive results. Therefore, more studies are needed to shed light on these inconclusive results and to provide evidence from other geographical contexts (Nielsen 2010)

The main aim of this paper is to find out how the diversity of top management teams (TMT), understood as variety (Harrison and Klein 2007) affects the international success and survival of companies in an emerging country. The study focuses on Spanish foreign direct investments (FDI) in China for several reasons. Firstly, because China is the largest recipient of FDI (The WorldBank 2013) and it offers great business opportunities (Sakarya et alii 2007; Enderwick 
2009;); secondly because it is not a common destination for Spanish companies, which have always preferred to invest in physically or culturally close countries (Johanson and Vahlne 1977) such as Europe or Latin-America; and thirdly because the cultural differences between China and Spain mean that more empirical evidence is needed on this type of Spanish FDI due to the notable differences in the institutional contexts of both countries and the risks and uncertainties involved in these Spanish FDI (Schmid and Wurster 2015). These difficulties justify the success and survival of Spanish companies investing in China as an interesting case study, and the analysis of the potential impact of the diversity of Spanish TMT on these variables related to internationalisation.

In order to answer the research questions, this article has been structured as follows: in the second section the previous literature on TMT and internationalisation is reviewed. In the third, the sample and methodology used in the study is justified. In the fourth, the results are reported and in the fifth discussed. Finally, the main conclusions are outlined in the last section.

\section{Theoretical framework and hypotheses}

Internationalisation is a business growth strategy influenced, like other strategic decisions, by decision-making bodies. The theoretical perspective adopted in this study to link the TMT with internationalisation is the Upper-Echelon Theory (Hambrick and Mason 1984) because the TMT's backgrounds and psychological characteristics influence the decisions they make, so their influence on internationalisation is unquestionable.

Previous literature has pointed out the observable demographic characteristics defined by this theory in order to show that they influence the internationalisation of the company in two ways. On the one hand, previous research has studied the influence of each demographic trait on the expansion process and has made some interesting findings. For example, internationalisation has been shown to have a negative relationship with TMT age, measured as the percentage of assets attributed to a global market (Tihanyi et alii 2000; Herrmann and Datta 2005; Hsu et alii 2013) and a positive relationship with TMT education (Moreira et alii 2013) and international experience (Tihanyi et alii 2000; Hutzschenreuter and Horstkotte 2013; Piaskowska and Trojanowski 2014). On the other hand, it is not only the individual characteristics of the TMT members that influence the strategic outcome of the internationalisation process of a company; the diversity of these characteristics within the TMT also has an effect, and in this regard, previous research has not reached a generalised consensus. 
Some authors argue that TMT diversity makes companies perform better because top managers come from different backgrounds and this increases the quality of decisions due to the differences in knowledge and perspectives (Pegels et alii 2000; Carpenter and Sanders 2004), especially in uncertain environments (Cannella Jr et alii 2008). Others, however, warn of the risks of conflict to which this diversity leads (Pelled et alii 1999; Carson et alii 2004). The heterogeneity of the TMT improves decision-making in some aspects but not in others because it makes the process slower (Hambrick et alii 1996).

Below we explain the relationship that certain demographic variables (age, gender, function, tenure and education) have on internationalisation according to the literature.

\subsection{Age diversity}

Age is one of the demographics that influence strategic decision-making (Wiersema and Bantel 1992). It is often related to previous experience and affects the propensity for internationalisation in several ways.

Young managers are more likely to make risky decisions so this may be beneficial for the internationalisation outcomes of the company (Herrmann and Datta 2005). In the same way, older managers are usually more risk averse and they prefer less uncertain strategies (Child 1974); this is because, on the one hand, they need to maintain their status and, on the other, they do not have the capacity to analyse and process the information they need to adapt to environmental changes, as young managers have (Herrmann and Datta 2005; Chen 2011). In this respect, age is negatively associated with internationalisation outcomes (Hsu et alii 2013).

However, previous experience, which is the other aspect related to age, may be associated with the propensity to internationalise and its success in just the opposite way (Hutzschenreuter and Horstkotte 2013). Therefore, a balanced TMT in terms of age could be one way of generating optimal results (Tihanyi et alii 2000), despite the fact that other authors suggest that age homogeneity leads to better performance. Whatever the case may be, we believe that the combination of youth and experience can generate the best partnership to leverage the strengths of each age group. In accordance with the above, we have formulated the following hypotheses:

- H1a. Age diversity of the TMT positively affects success abroad.

+ H1b. Age diversity of the TMT positively affects the survival of the company abroad. 


\subsection{Gender diversity}

The economic literature contains numerous gender studies because of the differences between the social preferences, risk and competitiveness of men and women, characteristics that condition their strategic decisions (Croson and Gneezy 2009).

Some results of previous studies indicate that female participation in the upper echelons increases the value of a company (Hassan et alii 2016) but others say just the opposite, that female directors report lower total shareholder return (Lückerath-Rovers 2013) and do not improve company performance (Darmadi 2013). Gender diversity can also cause conflicts (Richard et alii 2004) but some studies show the presence of women in government bodies and their effect on a company's results in a positive light (Liu et alii 2014). They bring other qualities or skills, which can favour, for example, innovation (Torchia et alii 2011; RegueraAlvarado et alii 2015) or RSC initiatives that generate greater organisational efficiency (Ben-Amar et alii 2015).

The number of women is also important since more than two generate better results (Liu et alii 2014; Nguyen et alii 2015). However, even if they have the same qualities or requirements as men, they are rarely hired despite the benefits discussed above (Nekhili and Gatfaoui 2013). The arguments in favour of gender diversity bring up the following hypotheses:

- H2a. Gender diversity in the TMT positively affects success abroad.

- H2b. Gender diversity in the TMT positively affects the survival of the company abroad.

\subsection{Functional diversity}

The functional background of managers influences their strategic decisions (Hambrick and Mason 1984). According to previous literature, different functional backgrounds have positive effects on internationalisation (Auden et alii 2006; Rivas 2012). This could be because managers from different functional areas also collaborate by increasing organizational creativity, which has a positive effect on the company's flexibility (Yoon et alii 2015). In this respect, Gevers et alii (2015) conclude that rather than homogenizing team structures, managers should stimulate good teamwork behaviour in an attempt to integrate interests and insights from different functional areas. So, a diversity of approaches can be necessary for companies because it provides an overview of the complexity of the internationalisation process, especially in new destinations. Therefore:

- H3a. Functional diversity of the TMT positively affects success abroad. 
- H3b. Functional diversity of the TMT positively affects the survival of the company abroad.

\subsection{Tenure diversity}

When a TMT works together for a long period of time it develops similar attitudes. Therefore, tenure affects the decisions they make (Katz 1982). In this respect, studies have been made of whether long tenure, both in a job or inside the organisation, favours strategic changes and the company internationalisation or not. Results have not been conclusive.

Some authors argue that long term TMTs are more resistant to change so they are less likely to undertake complex and risky processes such as those involved in internationalisation strategies (Finkelstein and Hambrick 1996). They may also have a skewed vision of the environment because having experience in other companies, in other contexts or other functions enriches knowledge. So, shorter tenures may have a positive relationship with international diversity (Herrmann and Datta 2005).

On the other hand, long tenures have some positive aspects. They are associated with stability, less conflict and efficiency (Katz 1982; Pelled et alii 1999 ) and this is good for internationalisation because it fosters consensus on strategy (Barkema and Shvyrkoc 2007). Authors like Chen (2011) found a positive relationship between tenure and internationalisation, measured in this case, as the ratio of foreign sales to total sales, due to the richness of long experience within a particular company.

Just like age diversity, tenure diversity is positive for company results (Auden et alii 2006; Tihanyi et alii 2000) because it allows for the creativity and freshness needed in foreign markets while maintaining stability and cooperation (Jaw and Lin 2009). Thus:

- H4a. Tenure diversity of the TMT positively affects success abroad.

- H4b. Tenure diversity of the TMT positively affects the survival of the company abroad.

\subsection{Diversity of educational background}

The educational background of the TMT brings together different factors, skills, knowledge and capacities that enable companies to improve their strategic decisions and perform better in complex situations (Carpenter 2002).

Higher educational levels have been linked to innovation (Camelo-Ordaz et alii 2005), openness to change (Wiersema and Bantel 1992; Díaz-Fernández et 
alii 2015) and also more international diversity (Tihanyi et alii 2000; Barroso et alii 2011; Hsu et alii 2013). The uncertainties associated with internationalisation makes it essential to have well-prepared managers with greater informationprocessing abilities if companies are to be successful in the international context (Herrmann and Datta 2005; Latukha and Panibratov 2015).

The literature has shown that a high level of heterogeneity in education positively affects internationalisation (Carpenter 2002., So:

- H5a. Diversity of educational background in the TMT positively affects success abroad.

- H5b. Diversity of educational background in the TMT positively affects the survival of the company abroad.

Figure 1 shows the relationships that this study will try to prove between the demographics of the TMT and its influence on the process of internationalisation.

Figure 1. The influence of TMT characteristics on internationalisation:

\section{hypothesis}

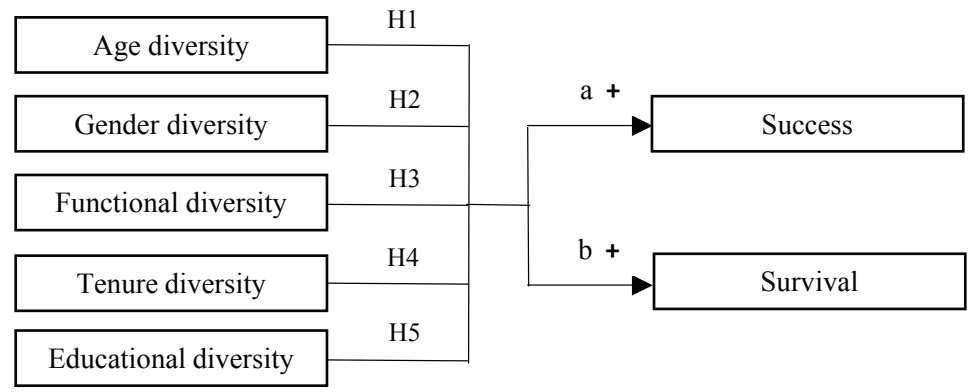

\section{Methodology}

\subsection{Data gathering}

The sample for the study was selected from the ICEX directory (Spanish Institute of Foreign Trade) and from the SABI database (Sistema de Análisis de Balances Ibéricos). We took into consideration Spanish companies with direct investment in China in 2012 regardless of their legal form. In total, 377 companies were identified. We contacted them first by phone to explain the nature of the study, before sending them the questionnaire in 2012 .

The questionnaire was addressed to the Chief Executive Officer or to the person responsible for business development via email with a link so that it could be answered online. The questions refer to seven different aspects 
of the company and its internationalisation process: the company's general information, the company's international experience, TMT data, the company's internationalisation process in general, the company's process of expansion (specifically in China), the company's human resource practices in the host country and the company's results abroad. Finally 82 responses were collected during the period 2012-2013, which represents a response rate of the $21.75 \%$. This ratio is better than other studies using questionnaires as a tool for data collection (Torchia et alii 2011; Moreira et alii 2013; Tolstoy 2014). We conducted a Student's t-test to determine if there was a significant difference in terms of size (measured as employees and total assets) and ROA (return on assets) between the respondents and the non-respondents and there was not (with a confidence level of 95\%). We compared the three control variables used in the model. For size, considering the number of employees, the t-statistic was 0.362 and its p-value 0.717. Taking the total assets the Student's t-test returned a value of 0.847 and a $\mathrm{p}$-value 0.847 . And, considering the ROA, the t-statistic was -1.366 and the p-value 0.175 . Table 1 shows some descriptive data of the respondents.

Table 1. Characteristics of the sample

\begin{tabular}{|l|l|l|}
\hline Industry & Manufacturing and construction & $45.1 \%$ \\
& Wholesale and retail trade & $23.2 \%$ \\
& Services & $30.5 \%$ \\
& NA & $1.2 \%$ \\
\hline Family business & Yes & $40 \%$ \\
& No & $60 \%$ \\
\hline Company size & Small & $11.0 \%$ \\
& Medium & $13.4 \%$ \\
& Large & $73.2 \%$ \\
& $\mathrm{NA}$ & $2.4 \%$ \\
\hline Years of experience & $\leq 5$ & $34.1 \%$ \\
in China & $5<\mathrm{X} \leq 10$ & $25.6 \%$ \\
& $10<\mathrm{X} \leq 15$ & $13.4 \%$ \\
& $15<\mathrm{X}$ & $15.9 \%$ \\
& $\mathrm{NA}$ & $11.0 \%$ \\
\hline
\end{tabular}

According to these data, the activities of the Spanish companies in China are mostly manufacturing, retail and professional services. They are basically large companies, because it is difficult for a small company to undertake a process of this nature largely due to lack of resources (Fernández and Nieto 2005; Harvey 
and Abor 2009; Lin 2010)using the Regional Project on Enterprise Development (RPED. And as can be seen by their experience in China, most of the companies in our sample settled in the country less than ten years ago so it is a relatively new destination.

\subsection{Measurement of the variables}

\subsubsection{Dependent variables}

Many parameters can be used to measure success and survival abroad: economic performance, financial ratios, market share, brand value, customer satisfaction, corporate image, etc. However, by asking the managers responsible for the internationalisation process, we seek in this paper to bring all these aspects together and determine whether the company believes that the result of its investment in China is being positive. Even if the investment is positive for the company, this does not necessarily mean that the associated ROA is positive as can be seen in the economic information of the sampled companies. This may be because China is a relatively new investment destination and companies still have to absorb the high initial costs (of investment and adaptation to the market). Also the current economic situation has affected company profits.

The last part of the questionnaire was about the company's results in China, and attempted to determine the internationalisation performance of the companies. There were six questions which had to be answered on a 5-point Likert scale (where 1 means "strongly disagree" and 5 means "strongly agree"). We conducted a factor analysis of these questions with principal component analysis as the extraction method and Varimax Kaiser Normalisation as the rotation method. The result was consistent according to the Kaiser-Meyer-Olkin measure of sampling adequacy (0.549) and Bartlett's test of sphericity was significant. Thus, the results support two factors of internationalisation performance with an eigenvalue greater than 1 . We identified two factors that explain $65.73 \%$ of the variance, clearly labelled as success and survival of the company in the host country (table 2). Therefore, we used these factors as dependent variables in our model. 
Table 2. Results of the factor analysis (Table of rotated component matrix)

\begin{tabular}{|l|r|r|}
\hline \multirow{2}{*}{} & \multicolumn{2}{|c|}{ factor } \\
\cline { 2 - 3 } & success & survival \\
\hline Investing in China has been successful. & .646 & .241 \\
\hline Success in China is saving the company. & .071 & .892 \\
\hline The company is successful if it is compared with its competitors. & .797 & .107 \\
\hline The company will still be successful in 5 years' time. & .871 &. .041 \\
\hline $\begin{array}{l}\text { The success of the investment will continue saving the company in } \\
\text { 5 years' time }\end{array}$ & .091 & .886 \\
\hline $\begin{array}{l}\text { The company will be successful if it is compared with its } \\
\text { competitors in 5 years' time }\end{array}$ & .683 & .022 \\
\hline Eigenvalue & 2.46 & 1.49 \\
\hline Percentage of variance & 65.734 \\
\hline
\end{tabular}

\subsubsection{Independent variables}

The independent variables of the study are the diversity of the demographic characteristics of the TMT. The CEO and four other members of the company's TMT were asked for their demographic information. Specifically, the variables that we considered were: age, gender, educational background, experience, organisation tenure and functional tenure. To analyse the diversity of the TMT we made some transformations. For qualitative variables we used the Blau Heterogeneity Index (Blau 1977) the formula of which is $1-\nabla p_{k}{ }^{2}$, where $p$ is the proportion of unit members in the kth category. A high score on this index indicates greater diversity, while a low score represents greater homogeneity. To calculate the diversity of the quantitative variables we used the variation coefficient (typical deviation divided by the average). After that, we used the $z$-score of the diversity variables.

\subsubsection{Control variables}

We introduced two control variables commonly used in internationalisation research: size and profitability. We determined the company's size through its assets (A) and the total number of employees (E). Profitability was measured in terms of the ROA. We used the logarithm transformation of the size variables, and then standardised all control variables ( $z$-score).

Table 3 shows some descriptive data of the variables and their correlations. It can be observed that the companies in the sample do not have a great deal of 
age and gender diversity in their TMTs according to their mean values. Diversity is greatest in both tenures, organisational and functional. As far as the control variables are concerned, it is noted that the average ROA is negative, which means that the year 2012 was not a profitable year, in general, for companies investing in China due to the global crisis.

Some variables have significant correlations between one another (see Table 3). The strongest relationship was found between variables $\operatorname{LogSize}(\mathrm{E})$ and $\operatorname{LogSize}(\mathrm{A})$, which is because both are related to company size although they are measured differently. To determine whether these correlations could create collinearity problems FIV values were also calculated. In all cases the values were below 10 which means that there are no serious problems in this regard (Kleinbaum et alii 1988).

\section{Table 3. Descriptive statistics and matrix of correlation of the independent variables}

\begin{tabular}{|c|c|c|c|c|c|c|c|c|c|c|c|c|}
\hline Variable & mean & SD & 1 & 2 & 3 & 4 & 5 & 6 & 7 & 8 & 9 & $\begin{array}{r}\text { FIV } \\
\text { values }\end{array}$ \\
\hline 1. AgeDiv & .1584148 & .09085785 & 1 & & & & & & & & & 1.465 \\
\hline 2. GenderDiv & .1960784 & .25236940 & -.008 & 1 & & & & & & & & 1.438 \\
\hline 3.OrgTenureDiv & .4924818 & .36846165 & -.008 & .115 & 1 & & & & & & & 1.303 \\
\hline 4. FunTenureDiv & .5737100 & .38342423 & $.345^{*}$ & .241 & .144 & 1 & & & & & & 1.886 \\
\hline 5. EducDiv & .3459764 & .25354579 & .299 & .117 & .152 & $.773^{* *}$ & 1 & & & & & 1.929 \\
\hline 6. ExpDiv & .4782385 & .28477742 & .277 & -.008 & $.760^{* *}$ & .144 & .063 & 1 & & & & 1.384 \\
\hline 7. ROA & -4.4213 & 35.07461 & $-.414^{* *}$ & -.081 & -.053 & -.126 & -.149 & -.024 & 1 & & & 1.553 \\
\hline 8. LogSize (E) & 1.9916 & .84596 & $-.335^{\star}$ & .060 & $.350^{*}$ & -.059 & .013 & .233 & $.239^{*}$ & 1 & & 4.055 \\
\hline 9. LogSize (A) & .5063 & .60926 & $-.370^{*}$ & .025 & $.399^{ \pm x}$ & -.180 & -.117 & $.323^{*}$ & $.369^{* * t}$ & $815^{* *}$ & 1 & 3.543 \\
\hline
\end{tabular}

\subsection{Data analysis}

Data were analysed using linear regression, following the Backward Stepwise Regression procedure. This method makes it possible to enter all the explanatory variables at an early stage. The variable with the smallest partial correlation with the dependent variable is then excluded. Once the first variable has been excluded, the process is repeated with the following variable with the smallest partial correlation. The procedure ends when there are no more variables in the equation that satisfy the exclusion criterion ( $F$ probability to be excluded P0.1) (Fitó-Bertran et alii 2015).

The results of the linear regression analysis carried out are reported below. 


\section{Results}

Taking the success factor as the dependent variable (Model 1 shown in Table 4), the final model after the Backward Stepwise Regression method has been applied has an adjusted $\mathrm{R}^{2}$ of $17.4 \%$. In the end, just one characteristic of TMT diversity is significant to determining the company's success in China: the age diversity of the TMT. This variable is significantly linked to success in a negative way: the greater the age diversity in the TMT, the less likely it is for internationalisation to be a success. So, H1a is rejected because age diversity in the TMT does not have a positive effect on success abroad. Hypotheses $\mathrm{H} 2 \mathrm{a}, \mathrm{H} 3 \mathrm{a}, \mathrm{H} 4 \mathrm{a}$ and $\mathrm{H} 5 \mathrm{a}-$ which attempt to relate the variables of gender, functional, tenure and educational diversity to success abroad - are not significant in Model 1, so we cannot reject or accept them.

Table 4. Linear regression of the success factor according to TMT diversity characteristics

\begin{tabular}{|c|c|c|c|c|c|}
\hline \multirow[t]{2}{*}{ Model 1} & \multicolumn{2}{|c|}{$\begin{array}{c}\text { Unstandardized } \\
\text { coefficients }\end{array}$} & \multirow{2}{*}{$\begin{array}{c}\begin{array}{c}\text { Standardised } \\
\text { coefficients }\end{array} \\
\text { Beta }\end{array}$} & \multirow[t]{2}{*}{$t$} & \multirow[t]{2}{*}{ Sig. } \\
\hline & B & Standard error & & & \\
\hline (Constant) & .128 & .158 & & .814 & .423 \\
\hline $\mathrm{ROA}$ & -.492 & .192 & -.457 & -2.562 & .016 \\
\hline Age diversity & -.349 & .173 & -.359 & -2.011 & .054 \\
\hline
\end{tabular}

Dependent variable: Success

In addition, the return on assets (ROA) is significant in Model 1 , and shows a negative relationship with the company's success. This means that the companies that are most successful in their attempts at internationalisation in China are also less profitable.

When the survival factor is taken as the dependent variable (Model 2 shown in Table 5), the same statistical method gives an adjusted $\mathrm{R}^{2}$ of $27 \%$. In this case, the diversity that affects survival abroad is gender diversity. Model 2 explains a positive relationship between gender diversity within the TMT and the company's survival in China, so $\mathrm{H} 2 \mathrm{~b}$ is accepted. The other hypotheses, related to diversity and survival ( $\mathrm{H} 1 \mathrm{~b}, \mathrm{H} 3 \mathrm{~b}, \mathrm{H} 4 \mathrm{~b}$ and $\mathrm{H} 5 \mathrm{~b}$ ), cannot be accepted or rejected, as they appear to be statistically non-significant in Model 2. 
Table 5. Linear regression of the survival factor according to TMT diversity characteristics

\begin{tabular}{|l|r|r|r|r|r|}
\hline \multirow{2}{*}{ Model 2} & \multicolumn{2}{|c|}{$\begin{array}{c}\text { Unstandardized } \\
\text { coefficients }\end{array}$} & $\begin{array}{c}\text { Standardised } \\
\text { coefficients }\end{array}$ & \multirow{2}{*}{$\mathrm{t}$} & \multirow{2}{*}{ Sig. } \\
\cline { 2 - 4 } & \multicolumn{1}{|c|}{$\mathrm{B}$} & Standard error & \multicolumn{1}{c|}{ Beta } & & \\
\hline (Constant) & .041 & .156 & & .264 & .794 \\
\hline Size (Assets log) & -.672 & .207 & -.522 & -3.247 & .003 \\
\hline Gender diversity & .400 & .201 & .320 & 1.991 & .057 \\
\hline
\end{tabular}

Dependent variable: Survival

The control variable size, which is also significant, indicates that smaller companies have greater survival.

\section{Discussions}

In this study we focused on the internationalisation outcomes of Spanish companies in China, a culturally distant country that makes the process more complex and risky (Hutzschenreuter and Horstkotte 2013). In this environment, the results show that the diversity of some TMT demographic characteristics affect the success and the survival of the company.

Although it has been shown in the literature that different types of diversities of the members of the TMT positively or negatively affect the internationalisation of a company, in our sample of Spanish companies with FDI in China only age diversity appears to have a significant effect on success. The other characteristics of diversity do not seem to affect the process. So, according to the data analysis, age diversity has a negative effect on international success in China. This could be explained by emotional conflicts related to this kind of diversity. People of a similar age are likely to have the same values and beliefs because their life experiences are similar (Ireland et alii 1987), thereby increasing the propensity to agree (Knight et alii 1999). In this regard, different generations have different perspectives on corporate strategy (Chen et alii, 2015) especially in a country that is so different culturally and so uncertain. Another reason may be because of the characteristics of our data. In our sample, a large number of companies are family owned (40\%), which may influence the relationship between age diversity and the internationalisation process negatively because of the potential conflict between the different generations of managers (Sciascia et alii 2013). So, we can conclude that an international company with a homogeneous TMT in terms of age obtains better results in China, because it may avoid conflicts between TMT members who are relatives. 
This result is in line with those of previous research. For example, although Tihanyi et alii (2000) argue that age diversity generates a wide variety of viewpoints that can lead to changes, especially in complex environments, and therefore has a positive effect on internationalisation, they could not support these arguments with data. Also, Auden et alii (2006) concluded that the homogeneity of ages generates best performance in the international context.

The other analysis related to Model 1 shows a negative relationship between ROA and international success. This is not an unusual result because foreign investment generates high costs, especially at the beginning of the internationalisation process and making a profit takes time (Contractor 2007). Of the countries in our sample, 34\% had been in China for less than 5 years, and more than $50 \%$ less than 10 years. Companies frequently need more time to achieve good levels of profitability. Previous research has also found smaller profitability ratios in companies with higher levels of international success $(\mathrm{Lu}$ and Beamish 2001).

Model 2, in which the dependent variable was survival abroad, is influenced by gender diversity and the size of the company. The fact that company size has a negative impact on business survival makes sense since small companies are associated with flexibility (Narula 2004) and adapting more easily to the everchanging and complex environment (Tolstoy 2014). In our study of an emerging country, the large number of changes in a short period of time in the market and legislation show the importance of flexibility. Therefore, small companies, which are normally more flexible, are those with the highest survival rates.

According to our data, gender diversity also has a positive effect on the survival of companies in China. This effect was also found by other authors, especially in companies seeking growth (Dwyer et alii 2003) and with geographically dispersed teams (Post 2015)this study examines how team leader gender relates to team cohesion, cooperative learning, and participative communication. Furthermore, the study argues that advantages derived from female leadership may be contingent on teams $\backslash$ u2019 coordination requirements. I propose that as teams $\backslash$ u2019 coordination requirements increase (i.e., with functional diversity, size, and geographic dispersion, as is the case of internationalisation.

The fact that women are more risk averse than men (Croson and Gneezy 2009) is consistent with our findings that gender diversity has a positive influence on the survival of international companies. There are several reasons for this. Firstly, internationalisation is a complex strategy with a high degree of uncertainty, so if women are less likely to make risky investments it is plausible that the ones they do make will be more successful and that companies with greater gender 
diversity will have greater survival rates. And secondly, because they take fewer risks, they also prefer to invest in lower-risk countries where the company has a greater chance of survival, so they do not choose an emerging country unless the investment opportunity is very favourable. Therefore, a balance between men and women in the TMT makes the company strategy less risky, which improves its chances of survival in an emerging market such as China. They can also bring qualities and skills that better suit Chinese culture such as patience and caution (Graham and Mark Lam 2003).

\section{Conclusions, limitations and future research}

In the context of this article, in which investment is made in an emerging market with considerable cultural differences, complexity and uncertainty, the role of the TMT can be even more important because it is more difficult for managers to effectively interact with local authorities, employees or clients.

On the basis of the results, we conclude that teams with a diversity of ages negatively affect the success of companies abroad. Instead, gender diversity increases company survival. In this respect, smaller companies tend to be more flexible and therefore have a greater ability to adapt to market contingencies.

These findings are relevant for companies because internationalization is a complex and risky process that is influenced by many variables, some internal and others external to the company. One of the factors that a company can control is the composition of the TMT. So, the contribution that this study makes to the international business literature in the field of emerging markets is that it determines what traits of TMT as a group favour the success of the internationalization process. TMT heterogeneity can be positive or negative for company results as it can hamper decision-making or generate better strategies because it takes more points of views into account. According to this study, age diversity means that companies are less successful in the context of investment in China. On the other hand, gender diversity generates greater survival in the same context.

These conclusions indicate that if companies want to invest successfully in China they need to have homogeneous teams in terms of age and to include women in their TMT.

This study also has its limitations. Firstly, it has a regional focus as it only covers Spanish companies that decide to internationalise in China, so it would be interesting to compare our results with those obtained from other Western countries, and to analyse whether they give the same importance to age and gender diversity in success and survival in the international context. Secondly, it 
would be interesting to collect more information to find if in the case of China there are other diversity variables of the TMT that can affect company results.

It would also be interesting to investigate if conflict within the TMT can have a positive effect on performance because different viewpoints about company strategy does not necessarily need to be negative. These research lines may be interesting for the future.

\section{References}

Auden, W. C.; Shackman, J. D., and Onken, M. H. (2006). “Top management team, international risk management factor and firm performance." Team Performance Management: An International Journal, 12(7/8), 209-224. <http://doi.org/10.1108/13527590610711778>.

Barkema, H. G., and Shvyrkoc, O. (2007). "Does top management team diversity promote or hamper foreign expansion?" Strategic Management Journal, 28, 663-680. h<ttp //doi.org/10.1002/smj>.

Barroso, C.; Villegas, M. M., and Pérez-Calero, L. (2011). "Board Influence on a Firm's Internationalization." Corporate Governance: An International Review, 19(4), 351-367. <http://doi.org/10.1111 /j.1467-8683.2011.00859.x>.

Ben-Amar, W.; Chang, M., and McIlkenny, P. (2015)."Board gender diversity and corporate response to sustainability initiatives: evidence from the Carbon Disclosure Project." Journal of Business Ethics. <http://doi.org/10.1007/ s10551-015-2759-1>.

Blau, $\mathrm{P}_{+}(1977)$. Inequality and heterogeneity: A primitive theory of social structure. New York: Free Press.

Camelo-Ordaz, C; Hernández-Lara, A.-B., and Valle-Cabrera, R. (2005). "The relationship between top management teams and innovative capacity in companies." Journal of Management Development, 24(8), 683-705.

Cannella Jr, A. a; PARK, J., and Lee, H. (2008). “Top management team functional background diversity and firm performance: Examining the roles of team member colocation and environmental uncertainty." Academy of Management Journal, 51(4), 768-784.

Carpenter, M. (2002). "The implications of strategy and social context for the relationship between top management team heterogeneity and firm performance." Strategic Management Journal, 23(3), 275-284. <http://doi. org/10.1002/smj.226>. 
Carpenter, M., and Sanders, W. (2004). "The effects of top management team pay and firm internationalization on MNC performance." Journal of Management, 30(4), 509-528. <http://doi.org/10.1016/j.jm.2004.02.001>.

Carson, C. M.; Mosley, D. C., and Boyar, S. L. (2004). "Performance gains through diverse top management teams." Team Performance Management: An International Journal, 10(5/6), 121-126. <http://doi. org/10.1108/13527590410556845>.

Chen, H.-L. (2011). "Does board independence influence the top management team? Evidence from strategic decisions toward internationalization." Corporate Governance: An International Review, 19(4), 334-350. <http:// doi.org/10.1111/j.1467-8683.2011.00850.x>.

Chen, Y.-M.; LiU, H.-H.; Ni, Y.-T., and Wu, M.-F. (2015). "A rational normative model of international expansion: Strategic intent perspective, market positions, and founder CEOs/family-successor CEOs." Journal of Business Research, 68(7), 1539-1543. <http://doi.org/10.1016/j. jbusres.2015.01.048>.

Child, J. (1974). "Managerial and organizational factors associated with company performance." Journal of Management Studies, 11(3), 175-189. <http://doi.org/10.1111/j.1467-6486.1974.tb00693.x>.

Contractor, F. J. (2007). "Is international business good for companies? The evolutionary or multi-stage theory of internationalization vs transaction cost perspective." Management International Review, 47(September 2006), 453475.

Contractor, F. J.; Kumar, V., and Kundu, S. K. (2007). "Nature of the relationship between international expansion and performance: The case of emerging market firms." Journal of World Business, 42(4), 401-417. < http:// doi.org/10.1016/j.jwb.2007.06.003>.

Croson, R., and Gneezy, U. (2009). "Gender Differences in Preferences." Journal of Economic Literature, 47(2), 448-474. <http://doi.org/10.1257/ jel.47.2.448>.

DARMADI, S. (2013). "Do women in top management affect firm performance? Evidence from Indonesia." Corporate Governance, 13(3), 288-304. <http:// doi.org/10.1108/CG-12-2010-0096>.

Díaz-Fernández, M. C.; González-Rodríguez, M. R., and Pawlak, M. (2014). "Top management demographic characteristics and their influence on strategic change." Industrial Management E Data Systems, 114(3), 365386. <http://doi.org/10.1108/IMDS-04-2013-0210>. 
Díaz-Fernández, M. C.; González-Rodríguez, M. R., and Simonetti, B. (2015). "Top Management Teams' demographic characteristics and their influence on strategic change." Quality E Quantity, 49(3), 1305-1322. <http://doi.org/10.1007/s11135-014-0053-4>.

Dwyer, S.; Richard, O. C., and Chadwick, K. (2003). "Gender diversity in management and firm performance: the influence of growth orientation and organizational culture" Journal of Business Research, 56(12), 1009-1019. <http //doi.org/10.1016/S0148-2963(01)00329-0>.

ENDERWICK, P. (2009). "Large emerging markets (LEMs) and international strategy" International Marketing Review, 26(1), 7-16. <http://doi. org/10.1108/02651330910933177>.

Fernández, Z., and Nieto, M. J. (2005). "Internationalization Strategy of Small and Medium-Sized Family Businesses: Some Influential Factors." Familiy Business Review, XVIII(1), 77-88.

Finkelstein, S., and Hambrick, D. C. (1996). Strategic leadership: Top executives and their effects on organizations (1st Ed.). South-Western Pub.

Fitó-Bertran, À.; Hernández-Lara, A. B., and López, E. S. (2015). “The effect of competences on learning results an educational experience with a business simulator." Computers in Human Behavior, 51, 910-914. <http:// doi.org/10.1016/j.chb.2014.11.003>.

Gevers, J. M.; Driedonks, B. A.; Jelinek, M., and Van Weele, A. J. (2015). "Functional diversity appropriateness: members' and managers' differential perceptions." Journal of Managerial Psychology, 30(6), 709 -725. <http://doi. org/10.1108/JMP-01-2012-0020>.

Graham, J. L., and Mark Lam, N. (2003). The Chinese negotiation. Harvard Business Review, 81(10), 82-91.

Graves, C., and Thomas, J. (2008). "Determinants of the internationalization pathways of family firms: An examination of family influence." Familiy Business Review, XXI(2), 151-166.

Hambrick, D. C.; Cho, T. S., and Chen, M.-J. (1996). "The influence of top management team heterogeneity on firms' competitive moves." Administrative Science Quarterly, 41(4), 659-684. <http»//doi.org/10.2307/2393871>.

Hambrick, D. C., and Mason, P. A. (1984). "Upper Echelons: The organization as a reflection of its top managers." Academy of Management Review, 9(2), 193-206. <http://doi.org/10.5465/AMR.1984.4277628>.

Harrison, D. a+, and Klein, K. J. (2007). "What's the difference? Diversity constructs as separation, variety, or disparity in organizations." Academy 
of Management Review, 32(4), 1199-1228. < http://doi.org/10.5465/ AMR.2007.26586096>.

Harvey, S. K., and АвоR, J. (2009). "Determinants of inward foreign direct investment in the Ghanaian manufacturing sector." Global Business and Economics Review, 11(2), 180-197. <http://doi.org/10.1504/ GBER.2009.028983>.

Hassan, R.; Marimuthu, M., and Johl, S. K. (2016). "Women on boards and market performance: An exploratory study on the listed companies." International Business Management, 10(2), 84-91. <http://doi.org/10.3923/ ibm.2016.84.91>.

Herrmann, P., and Datta, D. K. (2005). "Relationships between top management team characteristics and international diversification: an Empirical Investigation." British Journal of Management, 16(1), 69-78. $<$ http://doi.org/10.1111/j.1467-8551.2005.00429.x>.

Hsu, W.-T.; Chen, H.-L., and Cheng, C.-Y. (2013). "Internationalization and firm performance of SMEs: The moderating effects of CEO attributes." Journal of World Business, 48(1), 1-12. <http://doi.org/10.1016/j. jwb.2012.06.001>.

Hutzschenreuter, T., and Horstrotte, J. (2013). "Performance effects of international expansion processes: The moderating role of top management team experiences." International Business Review, 22(1), 259-277. <http:// doi.org/10.1016/j.ibusrev.2012.04.006>.

Ireland, R. D.; Hitt, M. A.; Bettis, R. A., and De Porras, D. A. (1987). "Strategy formulation processes: Differences in perceptions of strength and weaknesses indicators and environmental uncertainty by managerial level." Strategic Management Journal, 8(5), 469-485. <http://doi.org/10.1002/ smj.4250080506>.

JAw, Y.-L., and Lin, W.-T. (2009). "Corporate elite characteristics and firm's internationalization: CEO-level and TMT-level roles." The International Journal of Human Resource Management, 20(1), 220-233. <http://doi. org/10.1080/09585190802528797>.

Johanson, J., and VAhLne, J.-E. (1977). "The internationalization process of the firm - a model of knowledge development and increasing foreign market commitments." Journal of International Business Studies, 8(1), 23-32.

Katz, R. (1982). "The effects of longevity on project communication and performance." Administrative Science Quarterly, 27, 81-108. 
Kilduff, M*; Angelmar, R., and Mehra, A. (2000). "Top management team diversity and firm performance: Examining the role of cognitions." Organization Science, 11(1), 21-34.

Kleinbaum, D. G*; Kupper, L. L*, and Muller, K. E. E. (1988). Applied Regression Analysis and Other Multivariable Methods. Boston: PWS-Kent Publishing.

Knight, D*; Pearce, C. L.; Smith, K. G.; Olian, J. D*; Sims, H. P*; Smith, K. A., and Flood, P. (1999)."Top management team diversity, group process, and strategic consensus." Strategic Management Journal, 20(July 1998), 445465. <http://doi.org/10.1002/(SICI)1097-0266(199905)20:5<445ःAID$\mathrm{SMJ} 27>3.0 . \mathrm{CO} ; 2-\mathrm{V}>$.

Latukha, M. O., and Panibratov, A. Y. (2015). “Top management teams' competencies for international operations: do they influence a firm's result?" Journal of General Management, 40(4), 45-69.

LIN, F.-J. (2010). "The determinants of foreign direct investment in China: The case of Taiwanese firms in the IT industry." Journal of Business Research, 63 (5), 479-485. <http://doi.org/10.1016/j.jbusres.2009.04.005>.

Liu, Y., Wei, Z., and Xie, F. (2014). "Do women directors improve firm performance in China?" Journal of Corporate Finance, 28, 169-184. <http:// doi.org/10.1016/j.jcorpfin.2013.11.016>.

Lu, J. W., and BeAmish, P. W. (2001). "The internationalization and performance of SMEs." Strategic Management Journal, 22(6-7), 565-586. <http://doi. org/10.1002/smj.184>.

Lückerath-Rovers, M. (2013). "Women on boards and firm performance." Journal of Management \& Governance, 17(2), 491-509. <http //doi. org/10.1007/s10997-011-9186-1>.

Moreira, M. R. ; Maia, M. A.; Sousa, P. S., and Meneses, R. F. C. (2013). "Factors influencing the internationalization of services firms: The case of design, engineering and architecture consulting firms." Lecture Notes in Business Information Processing, 143, 246-262. <http://doi.org/10.1007/978-3-64236356-6_18>.

Musteen, M.; Datta, D. K., and Herrmann, P. (2009)."Ownership structure and $\mathrm{CEO}$ compensation: Implications for the choice of foreign market entry modes." Journal of International Business Studies, 40(2), 321-338.

Narula, R. (2004). "R\&D collaboration by SMEs: new opportunities and limitations in the face of globalisation." Technovation, 24(2), 153-161. <http://doi.org/10.1016/S0166-4972(02)00045-7>. 
Nekhili, M., and Gatfaoui, H. (2013). "Are demographic attributes and firm characteristics drivers of gender diversity? investigating women's positions on french boards of directors." Journal of Business Ethics, 118(2), 227-249. $<$ http://doi.org/10.1007/s10551-012-1576-z> .

Nguyen, T.; Locke, S., and Reddy, K. (2015). "Does boardroom gender diversity matter? Evidence from a transitional economy." International Review of Economics E Finance, 37, 184-202. <http://doi.org/10.1016/j. iref.2014.11.022>.

Nielsen, S. (2010)."Top management team diversity: A review of theories and methodologies." International Journal of Management Reviews, 12(3), 301316. <http://doi.org/10.1111/j.1468-2370.2009.00263.x>.

Pegels, C.; Song, Y., and Yang, B. (2000). "Management heterogeneity, competitive interaction groups, and firm performance." Strategic Management Journal, 21, 911-923. <http://doi.org/10.1002/1097-0266>.

Pelled, L. H.; Eisenhardt, K. M., and Xin, K. R. (1999). "Exploring the black box: An analysis of work group diversity, conflict, and performance." Administrative Science Quarterly, 44(1), 1-28. <http://doi. org/10.2307/2667029>.

Piaskowska, D., and Trojanowski, G. (2014).“Twice as smart? The importance of managers' formative-years' international experience for their international orientation and foreign acquisition decisions." British Journal of Management, 25(1), 40-57. <http://doi.org/10.1111/j.1467-8551.2012.00831.x>.

Post, C. (2015). "When is female leadership an advantage? Coordination requirements, team cohesion, and team interaction norms." Journal of Organizational Behavior, 36, 1153-1175. < http://doi.org/10.1002/ job.2031>.

Reguera-Alvarado, N.; de Fuentes, P., and Laffarga, J. (2015). "Does Board Gender Diversity Influence Financial Performance? Evidence from Spain." Journal of Business Ethics. <http://doi.org/10.1007/s10551-0152735-9>.

Richard, O.; Barnett, T.; Dwyer, S., and Chadwick, K. (2004)."Cultural diversity in management, firm performance, and the moderating role of entrepreneurial orientation dimensions." Academy of Management Journal, 47(2), 255-266.

Rivas, J. L. (2012). "Diversity \& internationalization: The case of boards and TMT's." International Business Review, 21(1), 1-12. <http://doi. org/10.1016/j.ibusrev.2010.12.001>. 
Sakarya, S*, Eckman, M., and Hyllegard, K. H. (2007). "Market selection for international expansion: Assessing opportunities in emerging markets." International Marketing Review, 24(2), 208-238. <http://doi. org/10.1108/02651330710741820>.

Schmid, S., and Wurster, D. J. (2015). "Internationalisation of upper echelons in different institutional contexts: top managers in Germany and the UK." European J. International Management, 9(4), 510-535.

Sciascia, S*; Mazzola, P., and Chirico, F. (2013)."Generational involvement in the top management team of family firms: exploring nonlinear effects on entrepreneurial orientation." Entrepreneurship: Theory and Practice, 37(1), 69-85. <http://doi.org/10.1111/j.1540-6520.2012.00528.x>.

The WorldBank (2013). "Foreign Direct Invesment, net inflows." Retrieved January 28, 2015, from <http //data.worldbank.org/indicator/BX.KLT. DINV.CD.WD?order=wbapi_data_value_2013+wbapi_data_ value+wbapi_data_value-last\&sort $=$ desc $>$.

Timanyi, L*; Ellstrand, A. E*; Daily, C. M., and Dalton, D. R. (2000). "Composition of the top management team and firm international diversification." Journal of Management, 26(6), 1157-1177. <http://doi.org/ 10.1177/014920630002600605>.

Tolstoy, D. (2014). "Differentiation in foreign business relationships: A study on small and medium-sized enterprises after their initial foreign market entry." International Small Business Journal, 32(1), 17-35. <http://doi. org/10.1177/0266242612456571>.

Torchia, M.; Calabrò, A., and Huse, M. (2011). "Women directors on corporate boards: From tokenism to critical mass." Journal of Business Ethics, 102(2), 299-317. <http://doi.org/10.1007/s10551-011-0815-z>.

Westphal, J. D., and Fredrickson, J. W. (2001). "Who directs strategic change? Director experience, the selection of new CEOs, and change in corporate strategy." Strategic Management Journal, 22(12), 1113-1137. <http://doi.org/10.1002/smj.205>.

Wiersema, M. F, and Bantel, K. A. (1992). "Top management team demography and corporate strategic change." Academy of Management Journal, 35(1), 91-121. <http://doi.org/10.2307/256474>.

Yoon, W; KIM, S. J., and Song, J. (2015).“Top management team characteristics and organizational creativity." Review of Managerial Science, 1-23. <http:// doi.org/10.1007/s11846-015-0175-7>. 